\title{
Tradition and Poverty Reduction - Mahalla and its Significance in Development Process in Tajikistan
}

\author{
Anna Cieslewska, University of Warsaw
}

\begin{abstract}
Significance of mahalla as informal social, self-governing institution has increased due to a variety of factors related to the post-transitional changes in Tajikistan. The phenomenon of existence of informal self-government bodies has not been only exclusive to Central Asia or Tajikistan. However, in a case of Central Asia, those institutions have always played significant role in maintaining social order and frequently they are more legitimized in the eyes of local residents than the formally established self-government. Recently, the government of Tajikistan has attempted to incorporate the elements of (indigenous) self-governmental institutions into the formal self-government's structures. Also, international organizations try to integrate mahalla as important element which would facilitate development's process. Identification of potential of this old institution could become a good base for poverty reduction and social programs.
\end{abstract}

JEL Codes: D7, D71, D78

\section{Introduction}

Self-govermentality has long lasting tradition in the cultures of Central Asia. Since centuries the self-government institutions such as mahalla have regulated life of communities. Despite the social changes which were brought by Soviet Union, mahalla played an important function during the whole soviet period, and a real role of Soviet Union in diminishing or reinforcing authority of mahalla is still discussed by scholars, politicians as well as development workers. Unquestionably, this old social institution outlive of the Soviet Union and its significance cannot be marginalized. After gaining independency by Tajikistan, the government sought to incorporate a concept of mahalla into the state system to legitimize its rules as well as to extend control over society. In spite of this, still mahalla has a wider, social recognition than the formal, governmental bodies. It has long-lasting authority in society and its importance was endured by hardship of a civil war (1992-1997), then the afterwards crisis. Despite the common Western view that traditional organization such mahalla cannot be considered as a form of civil society due to its patriarchal as well as segmentary character, mahalla still grasps great admiration of society that is much more bigger than have just recently established civic organizations or formal governmental bodies.

The presented paper considers traditional, central Asian institution - mahalla in a context of social cohesion which would reinforce poverty reduction and social development in Tajikistan. The paper is based on a field study which was conducted from June to September 2010 in the three regions of Tajikstan: the central part of the country - Gissara region, Shurabad district (Khalton region) which borders with Afghanistan, and Khujand region - the North part of the country. Research was carried out by a team of the Polish researchers: Professor Stanislaw Zapasnik, Mariusz Marszewski, PhD, and PhD student Anna Cieslewska.

\section{Institution of Mahalla - short overview}

The literal meaning of a word mahalla in Arabic is district. However, in the context of Central Asia, the original sense of the word "district" does not provide a precise understanding of the concept of mahalla. Apart from mahalla, among a sedentary population of Central Asia, there are other terms which describe a similar phenomenon such as $k u$ (Tajik/Farsi)/(English: road, a part of city), guzar (Tajik/Farsi)/(English: passage) - (a term of guzar is also used to described a small street within mahalla), also elat (tribe, family, country - this name for district 
was used only in Khiva), (Jasiewicz, 2004a) as well as chakar (Tajik) characterized for Sukh region (presently, Uzbekistan). According to Jasiewicz, the term elat, might be evidence of the strong divisions of tribes and ethnic groups in the past within the same territory. The oldest source which mentioned word mahalla, it is a history of Buchara written in twelfth century by Narshahi, although, the same concept was developed before Islamization of Central Asia (Niyazov, 2007a).

The meaning of those terms have been changing over time as well as region. All quoted names imply the integrated cluster of houses based on a different kind of the territorial, professional, family, or/and ethnic relationship, being incorporated into a city, town or settlement where a particular community is living. As Nizajov (2007b) indicates the problem with the precise definition of mahalla is related to its geographical form which is determined by a place where mahalla is built - usually mahallas which are located in a center of city/town are smaller. Mahalla can consists of several dozen or even several hundred houses build along big street with small side streets (organize in a form of quarter), or one, big street which is sometimes divided into two mahallas. Mahalla is also found in a rural area in the bigger settlements; usually all houses located within the border of a village make up one mahalla or a particular settlement is divided into a few smaller entities. Basically, mahalla is the smallest administrative unit which organizes life of community; a concept of mahalla is deeply embedded in collective consciousness of sedentary population of Central Asia as a form of social organization. In my opinion, idea of mahalla influenced social organization almost at the each level - even, in a modern apartment block, there are block committees which are partly followed the model of mahalla; for instance the Tajik $\mathrm{PhD}$ student being asked about her understanding of mahalla, answered that community who are living in a student hostel - it is also a kind of mahalla.

In terms of its social function, mahalla can be defined as a self-governing small community. However, there are very different ways of organizing malalla' society. Area of mahalla can be occupied by one ethnic group, one or more extended families such as avlod (Tajik)/(English: ancestors), qaum (Uzbek/Tajik)/(English: family), (a term varies from region to region); mahalla also can gathered representatives of different ethnic groups. In this case, a name of mahalla could be derived from the biggest ethnic group which is living there e.g.: mahalla Arabon - in the Old Buchara (where mainly, but not only Arabs were living), or if mahalla's vicinity was outnumbered by representatives of a particular professional group then it name was taken from that profession, i.e.: mahalla pachtabofon (mahalla weavers). Mahallas also can be named after mosque, local mazar (Tajk)/(English: cemetery - here a shrine), even waterfall, name of local heroes and the others (Niyazov, 2007c).

A way of functioning mahalla's community is based on the certain rules rooted in tradition, which regulate the social relations of mahalla's dwellers. Certainly, mahalla is indigenous, self governing body.

Prior to the October revolution, mahalla was treated as the semi- administrative unit of the city/town/settlement. The tsarist government administration was interested in maintaining mahalla as a form of self-governing organization which regulated social order at the local level. A head of mahalla, was always elected by its inhabitants, but his candidacy had to be approved by municipal authorities; he was also the lowest administrative representative in the hierarchy of city's administration (Jasiewicz, 2004b) .

Significance of mahalla as informal self-government organization was also recognized by the soviet authorities. In the aftermath of the revolutionary changes, a number of different kinds of the social committees sprang up i.e: in the early twenties meczetkoms and guzarkoms were established with intention to mingle ideas of a new communist ideology with the local tradition. In this way, the new, communist power tried to integrate Central Asians into the Soviet structures. Later then, mahallas committees played a role of important linkage between community and the state. They fulfill both - the traditional social function as well as a new role introduced by the Soviet authorities. For example, Jasiewicz (2004c) indicates that 
mahallas committees, besides its numerous social responsibilities, passed a certain political knowledge aimed at spreading the new, socialistic values among mahallas'dwellers. However, Abdullaeva and Turyaev (2004a) argue that during the Soviet period, the village councils were established as the legitimate, executive body, and mahalla's position decreased.

Nevertheless, a main role of mahalla during the soviet period was to maintaining traditional, social values. I am of the same opinion with Goziev, who points out that mahalla contributed to preserve the Islamic heritage (unpublished paper, 2008b).

From a point of view of the structure, it varies from region to region. However, the traditional mahalla maintains a chaikhana (Tajik)/(English: tea house) - a place for the meetings of community as well as people from outside (i.e.: officials). Sometimes chaikhana used to play a role of the mosque (such situation took place during the soviet period, when majority of mosques were closed). However, in mahallas which posses two institutions, their roles differ; the mosque is a very important place for religious life of the community; there is sometimes mazar (here: shrine) on the territory of mahalla which is important from the point of view of spiritual life of mahalla community. As a mosque is a place of worship accordingly to Islamic faith, and traditionally is attended only by men (women are not allowed to pray in a mosque in most countries of Central Asia), while mazar is a shrine which gathers both men and women; some rituals performed in mazars are rooted in pre-Islamic tradition; mazar also plays important role as a part of collective spirit of a certain community.

Every mahalla has a head (Tajik: raize or amin of mahalla) who traditionally was elected by community. He should be a trustworthy as well as distinct men, responsible for all mahalla's affairs; he has also his deputies (a committee of mahalla). Every side-street has its leaders who closely cooperate with raize/amin of mahalla (they are called raizes of guzare (Tajik)/(English: a head of side-street) or sometimes sardori kucha (Tajik)/(English: an elder of street). Together with the other significant male representatives of community, during the meetings in the mosques or chaikhana, they discuss important issues for community such as collective work (Tajik: hashar), necessary reparations, or the other socially important issues. According to tradition, in mahalla, money is collected to help the poorer members of the community as well as to meet the other social needs such as reparations and so forth (Goziev, unpublished paper, 2008a, Nijazov, 2006d). Hashar can be performed for benefit of whole community i.e.: repairing a public building or for a private purpose such as embroidering fabrics for someone dowry.

In the past in every mahalla, there was an informal institution of the Council of Elders, which played a regulatory role over the community life such as resolving conflicts among community members, mediations and so on. Nowadays, due to a rapid post-transitional changes, influences of elders have been decreasing, and it varies from mahalla to mahalla. However, elders still are asked about recommendations, also in majority mahallas, religious leaders contribute to discussion on important matters - mullas as well as sometimes women religious leader bibi halifa or bibi otum. They usually lead a circle of women who participate in organization of mahalla's rituals, celebration and the forth. Despite the fact that formally, all decisions are taken by a group of significant men and, they are approved by majlis (Arabic)/ (English: place of sitting/assembly) of all male representatives of mahalla, bibi halifa (Tajik.)/bibi otym/bibi mulla (Uzbek) is usually asked about opinion - they represent women's affairs in mahalla. In a case of a lack of women religious leaders, the other women are responsible for women's issues. The fact that majlis is traditionally attended only by men, arouses always controversy among western donors.

One of the most important factors which contributes to consolidation of community is collective participation in celebrations and rituals such as weddings, burials, circumcisions they are very important events of everyday mahalla's life. This fact integrates poor and reach members of community not only at the material level but also in spiritual way. 


\section{Contemporary mahalla in Tajikistan}

During the civil war in Tajikistan, the social recognition of mahalla as self-governing body increased due to decreasing state's activity at the local level. In fact, in many cases, mahalla operates more sufficiently that the formal local self- government (Tajik: jamoat), (jamoats is the smallest administrative unit in Tajikistan, and it consists of a several mahallas). Despite the fact that during the war humanitarian assistance was frequently channeled through jamoats, a role of mahallas' leader in aid delivery was significant as they were able to deal with conflicts in the villages, which increased during these times. Some international organizations channeled humanitarian aid through mahalla's authorities - such action significantly reinforce a position of mahallas' leaders. According to one of my interlocutors: mahalla'leader controlled over the humanitarian food distribution. It was relatively easier to make a pressure on jamoat's authorities to get aid products informally, conversely, due to the fact that mahalla' community is well integrated, it was much more difficult to misappropriate humanitarian aid.

During our research on mahallas in three different regions of Tajikistan, only few times, we had opportunity to observed significant contribution of the state in building new or maintaining old infrastructure. Mainly all reparations and small investments are financed by fund of mahalla with voluntary participation of community's members (hashar). In some cases, international donors contribute to local development. In the region of Gissara, we organized short, informal seminar with the representatives of two mahallas regarding writing project's proposal. The event was initiated by a head of women's local initiative group. Both mahallas undertook many enterprises such as road's reparation (two kilometers), reconstruction of water's channels, constructing water's pipe and the others. Any of those projects were neither facilitated nor financed by the state. All implemented activities were organized and financed only by mahallas's inhabitants. The participants of seminar expressed opinion that the state is too poor to contribute to local development's process and mahalla's community has to rely on itself. I heard such opinion many times during research. Ones I heard the following question from vice-raize mahalla: the bridge in our mahalla was broken - Do you know maybe some international donors who could contribute to its reparation? - frequently, people even do not consider that local formal authorities can provide any form of assistance.

Despite a low state's participation at the local level, authorities attempt to create mechanisms which would integrate mahalla into the state's system. In 2008, a new law was passed "the Law on Self-governing, Social Institutions” (Russian: “Закон Об Органах Общественной Самодеятельности"). According to a new law, civil society institutions such as mahallas are considered as the smallest self-government entities at the local level. Formally, mahalla can be registered as social institution with rights to maintain own banking account, stamp as well as to issue simple documents as certificate of permanent or temporary residency. Moreover, according to the new law in order to resolve social problems, they can cooperate with governmental and non-governmental bodies as well as international organizations operating in Tajikistan. Theoretically, the new law gives mahalla more competencies as well as a space to develop mahallas's social capita. In practice, a real capacity of mahalla is limited, since knowledge of the new law among members of mahallas' committees is inadequate, and majority of them do not understand the mechanism of work with international donors. Also, implementation of the new law encounters difficulties due to the fact that people doubt a real execution of the law.

In addition, the new law regulates activity of mahalla's committee. Mahalla committee plays a role of a representative organ of citizens. Integration of mahalla into the state system could contribute to improve cooperation between local formal self-government and society. However, it should be also indicated that mahalla committees could be a tool of extending control over society; due to the fact that a real contribution of jamoat to mahalls's life is questionable, authorities can use mahalla committees to influence community. The research data indicates that people rarely approached jamoat authorities with their problems. Traditionally, especially 
rural population do not apply to formal authorities to resolve any civil claims (property, religious divorce and the others), (Abdullaeva and Tyuryaev, 2004b).That is why mahallas' committee is a body which goes between community and jamoat. Nevertheless, owing to the different role and function of mahalla and jamoat, it is difficult to diminish a role of the latter. Undoubtedly, due to a lack of funds, the state which is at the local level represented by jamoat does not fulfill its duties, hence, partly its function is replaced by traditional, social institutions such as mahalla. However, still authorities try to avoid decentralization of the state's structures by expanding regulatory framework over life of mahalla's community.

In terms of its function, institution of mahalla tends to be stronger in the villages or smaller settlements than in the bigger urban units. Frequently, in the big cities a main task of mahalla's authorities is limited to collecting money for communal services, and its traditional, customary role is almost disappeared. One of the reasons of such situation is regular movement of inhabitants which results in a low level of community's integration. However, there are also strong mahallas in big cities and weak mahallas in villages.

The fact that mahalla is strong and well integrated in rural areas could be explained by long history of community living in the same place. For instance, we conducted research in the places where common memory of mahallas community dates back to seven hundreds or even one thousand years which means very strong social bonds (of course, due to a variety of reasons people moved during such long period, however, still community has common memory: ancestors, mazars and the like). The second important factor which reinforce of maintaining traditional, social order are religious institutions such as mosque or mazars, especially of those which are tombs of local saints. In one case, qaum of local, Islamic teacher who died in fourteenth century, and who was told to be a famous clairvoyant, has been still living in the village where there is the saint's mazar; some of his ancestors continue spiritual tradition of family as religious leaders.

From the point of view of social structure, the most important is a place of each extended family (avlod, qaum ect.) within a community. As Abdullaeve and Tyuryaev (2004c) indicate, social capita is accumulated by members of family from generation to generation (as well as negative deeds). It means that extended family consists of the living people as well as their ancestors - this fact contributes to strengthen social bonds. For instance, even if, presently, many people migrate to Russia, Kazakhstan and so forth for work, and they have been living abroad for years, they still participate in life of mahalla through linkage with their avlot as well as the other social networks i.e.: groups of the same age (Tajik: jura, dawra) and the like. So, many of them substantially contribute to mahalla funds, even sometimes financing certain enterprises i.e.: in one mahalla in Gissara, a part of water pipe was financed by a businessman living in Russia - a inhabitant of mahalla.

One of the most consolidated factor of mahalla's community is a person of raize mahalla. If raize mahalla has strong leadership skills - mahalla is well integrated. According to the local development worker, a sign of weakness of mahalla is degeneration of traditional order and values which are associated also with a person of raize mahalla. A work of a raize mahalla is unpaid, that is why, there are other advantages of holding this position such as gaining respect of everyone in mahalla. In the past raize was elected by community, whereas, nowadays, a raize is often recommended by local authorities, and he often represents only interests of a certain group of people. During a focus group with women from mahalla at the outer suburbs of Khujand city, I was told that a present raize who is a director of the school was appointed informally by jamoat authorities (during majlis his candidacy was only formally confirmed in an open voting) but he is not good raize because of he does not know the needs of community. According to respondents, good raize is a person who is strongly involved in the community's affairs, he should be experience as well as energetic, cleaver, and also he should possess respect of people.

Potential of indigenous institution such mahalla can be used to facilitate development programs implemented by international organizations. Although, mahalla is frequently 
considered by donors as undemocratic and unequal institution due to its segmentary character which for example disadvantages women in a process of decision making. There are a number of organizations which try to implement of the elements of mahalla structures into their projects by facilitating of mahalla's committees, creating variety of groups or integrating mahalla into the other structures. Though, majority of organizations desire to use mahalla institutions but in the same time they do not take into account the most important aspect of mahalla which is a division of community accordingly to social status, age, gender as well as education or descent from spiritual/religious leaders.

I had opportunity to participate in majlis which was organized by donor - International Funds for Agriculture and Development (IFAD). One of the requirements of the donor, was women' participation in public gatherings which aimed at facilitating a process of decision making. The assembly was organized at premises of the school in the following way: the mahalla elders were sitting in the main place, beside, the middle age men took the sits, then the young men followed; on the veranda which was placed quite far from the main part of the meeting, few women were gathered, and shortly after signing a list for participants, they left the place. One of the local development workers comment on that situation that women's participation in majlis is useless since tradition prevent them from expressing opinion in public. They will do it in home which eventually would influence opinion of their husbands but they would never openly tell what they think in a presence of the other male members of community. My interlocutor added that he personally raised the issue of women's participation during the meeting with donors but it did not cause any change in donor's policy. Above example well illustrate that integrating institution of mahalla could be beneficial for development programs, however, to achieve desirable goal it should be done with full recognition of local conditions. It means that in society with strong division into male and female worlds, merging two of them could not bring a wanted result.

\section{Summary}

Integrating traditional (indigenous) self-governing institution such as mahalla into poverty reduction's programs, could give a great potential for social as well as economic development. Mahalla has always played significant role in maintaining social order, and its informal, unwritten rules are frequently more sustainable and durable that formal codes. Unquestionably, mahalla's institution is inherent in the structures of the Tajik social life by either responding to its needs or controlling its function. A role of value system, traditions and beliefs should be incorporated into modern structures. All those means could be use for benefit of society. That is why, while planning development programs, representatives of international organizations should bear in mind the specific social conditions of each targeted environment.

\section{References}

- Z. Jasiewicz, 2004. Rodzina, społeczność lokalna i grupa etniczna w Polsce i Azji Środkowej. Wydaw. Poznańskie, Poznan

- A.Niyazow, 2007. "Mahalla a tradycje samorządowe w Azji Centralnej”, an excerpt of unpublihed master dissertation. Polish Academy of Science, Warsaw

- S. Goziev, 2008. "Traditional institutions in Tajikistan", unpublished paper

- Abdullaeva, M. and F. Tyuryaev, 2004. Role and place social institutions in a process of development village communities. ASTI, Khujand.

- “Закон республики таджикистан об органах общественной самодеятельности”, 2008. Dushanbe 